\title{
"WINS" untuk Pengelolaan Kawasan Lindung Berdasarkan Sistem Agroforestri Aren (Arenga pinnata) di Zona Rehabilitasi Taman Nasional Meru Betiri
}

\section{("WINS" for the Management of Protected Areas Based on Aren (Arenga pinnata) Agroforestry System in the Rehabilitation Zone of Meru Betiri National Park)}

\author{
Rahmatan $^{1 *}$, Yulia Raudhatul Balaqis Zahro', Safira Azizah²
}

(Received November 2019/Accepted February 2021)

\begin{abstract}
WINS" (Win-Win Strategy) in the management of protected areas is the strategy that benefit both parties. Agroforestry with forest trees accompanied by agricultural crops may benefits the community if it is implemented in line with the management of Meru Betiri National Park (TNMB) policies. The agroforestry plants proposed in this study were aren (Arenga pinnata), java chili (Piper retrofractum), and porang (Amorphophallus muelleri). This study recommends four strategies for better agroforestry practice in TNMB, i.e.,g. 1) strategy l, increasing public awareness of the urgency of the preservation of national park areas; 2) strategy II, formulating policies to support agroforestry as a strategic management effort; 3) strategy III, education and counseling, as a strengthening of the role of extension workers; and 4) strategy IV, facilitating access to relevant data across all participating institutions and is supported in a multidisciplinary manner. This model may be used as a reference for agroforestry models in conservation areas, especially in TNMB, which will optimize the development of native plants in an area.
\end{abstract}

Keywords: agroforestry, Arenga pinnata, Meru Betiri National Park, SWOT analysis, win-win strategy

\section{ABSTRAK}

WINS "(Win win Strategy) dalam pengelolaan kawasan lindung adalah strategi yang menguntungkan kedua belah pihak. Agroforestri dengan pohon-pohon hutan yang disertai dengan tanaman pertanian dapat menguntungkan masyarakat jika diterapkan sejalan dengan kebijakan pengelolaan Taman Nasional Meru Betiri (TNMB). Kebijakan tanaman agroforestri yang diusulkan dalam penelitian ini adalah aren (Arenga pinnata), cabai jawa (Piper retrofractum), dan cabai (Amorphophallus muelleri). Penelitian ini merekomendasikan empat strategi untuk praktik agroforestri yang lebih baik di TNMB, misalnya 1) strategi I, meningkatkan kesadaran masyarakat tentang urgensi pelestarian kawasan taman nasional; 2) strategi II, merumuskan kebijakan untuk mendukung wanatani sebagai upaya manajemen strategis, 3) strategi III, pendidikan dan konseling, sebagai penguatan peran pekerja penyuluh, dan 4) strategi IV, memfasilitasi akses ke data yang relevan di semua lembaga yang berpartisipasi dan didukung secara multidisiplin. Model ini dapat digunakan sebagai referensi untuk model agroforestri di kawasan konservasi, terutama di TNMB, yang akan mengoptimalkan pengembangan tanaman asli di suatu daerah.

Kata kunci: agroforestri, Arenga pinnata, Taman Nasional Meru Betiri, analisis SWOT, strategi wins

\section{INTRODUCTION}

The establishment of the National Park was designed to support and preserve natural resources with native ecosystems and a zoning system to allow the area to be used for research, science, education, supporting cultivation, tourism, and recreation

1 Departement of Forest Resources Conservation and Ecotourism, Faculty of Forestry and Environment, IPB University, IPB Darmaga Campus, Bogor 16680

2 Department of Forest Management, Faculty of Forestry and Environment, IPB University, IPB Darmaga Campus, Bogor 16680

* Correspondence Author:

Email: rahmatanscientist@gmail.com purposes. The national park area should be free from disturbances that may result in a malfunction of the area. However, changing land use and land conversion for agriculture and settlement make forest encroachment. Illegal ownership of the land and poverty may result in forest damage and deforestation in Indonesia, include disturbances to the national park. Therefore, a proper action is needed to provide a solution to resolve forest damage in a national park and mutually beneficial to the two parties, both the national park and the community. This action is called Wins, Win-Win Strategy in the management of protected areas that benefit both parties. Strengthening and obvious institutions are expected to be discovered by each party. 
Agroforestry is one of the methods used by the government to mediate conflicts such as forest encroachment for agricultural land, illegal logging, and black markets of wild animals and plants. Poverty in society brought these activities as a solution for survival. Agroforestry is a form of deliberate planting between staple crops and crops in a place (Bhagwat 2008).

Community participation determines the success of agroforestry in solving the problems of poverty and deforestation in Indonesia, especially in TNMB. Planting TNMB with aren (Arenga pinnata) and cabai jawa (Piper javanicum, java chilli) could provide economic benefits after planting. Porang (Amorphophallus muelleri) can benefit the TNMB parties by increasing the existence of native species while the community could cultivate in the rehabilitation zone. Agroforestry includes the sustainable use of natural resources by emphasizing the welfare of the community without damaging the environment.

\section{MATERIAL AND METHODS}

\section{Research Location and Time}

This research was carried out in Meru Betiri National Park (TNMB) in Ambulu Conservation II Section, Andongrejo Village (Figure 1). Data collection and analysis were conducted from June 2019 until August 2019.

\section{Tools and Materials}

The equipment used during the research were (1) Sketchup 2019; (2) Microsoft Office 2016; (3) digital cameras; (4) stationery; (5) additional data storage. The materials used during the research were: (1) Map of MBNP area; (2) Activity reports of MBNP; and (3) Interview questionnaire.

\section{Data Types and Sources}

This research was conducted, using primary data and secondary data. Types of primary data are information about social aspects, economic aspects, physical aspects of the research location, the data obtained from interviews with the communities around the research location. Meanwhile, secondary data obtained from the Meru Betiri National Park agency, journals, and the research related to forest land conversion.

\section{Data Collection Technique}

Data collected using survey methods, direct observation in the field, interviews with respondents to obtained facts in the form of social conditions, management and problems that exist in the area. Observations were made by looking at the actual development of national park conditions, jungle zones, rehabilitation zones, and the distribution of aren in national park. Interviews were addressed to the Meru Betiri National Park Office, chairman/member of the farmer's group. To support the primary data obtained, secondary data obtained from national park are needed

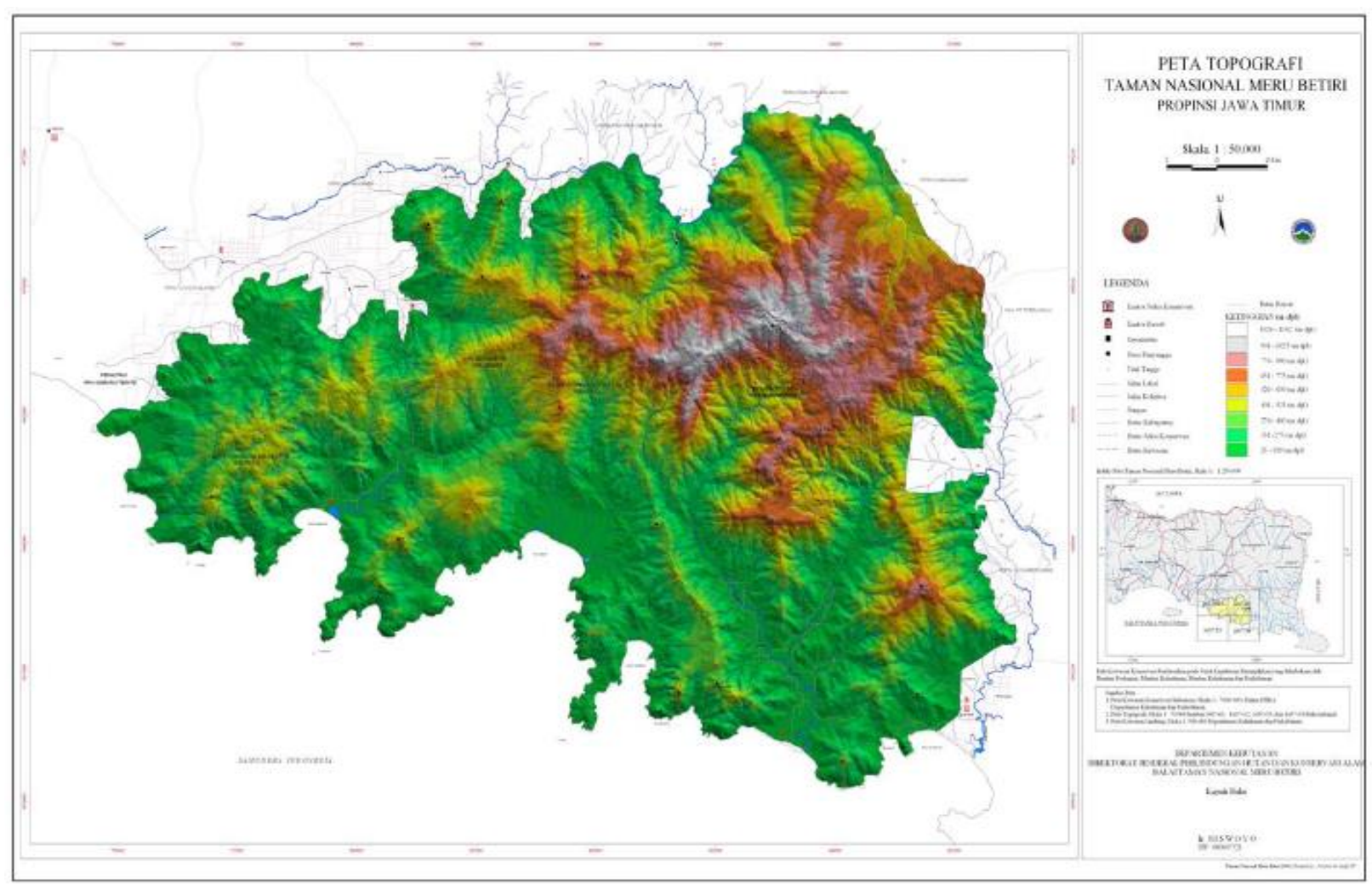

Source: Meru Betiri National Park.

Figure 1 Map of Meru Betiri National Park. 
which are related to the results of previous research. The data describes general conditions such as zoning, area, climate, and population.

\section{Data Processing and Analysis Methods}

The data presented were obtained from various stages namely:

The data collected is divided into three types, namely: communities social data, the Meru Betiri National Park (MBNP) ecosystem, and manager of the national park. For community socio-economic data such as education, knowledge, and community involvement got from previous research. For MBNP ecosystem data in the form of vegetation data, ecosystem damage, rehabilitation zone land condition, the latest data from MBNP manager. The current data from MBNP manager were recovery activities, policies, and agreements that have been implemented to the communities. The data previously mentioned, that can support agroforestry activities, then analyzed in a description to draw conclusion through a SWOT analysis. SWOT analysis uses the aspects of opportunities, threats, weaknesses, and strengths then process in the matrices.

\section{RESULTS AND DISCUSSION}

\section{Agroforestry Management Strategies}

The agroforestry systems used were aren as staple trees and java chili and porang as intercropped plants. Staple crops are conservation plants that are intentionally planted based on the recommendation of TNMB to restore ecosystems in the rehabilitation zone. When the agroforestry system reaches an optimal level, three types of stratum in the land will be formed. The strata begin with porang plants with 1-meter habitus, Java chili (2-3 meters), and aren (25 meters at a productive age).

Aren reaches productive age between 8-20 years, therefore farmers can use porang that are ready to harvest after 1-2 years, and Java chili that is ready to harvest after three years of planting. The nature of Java chili and porang plants can regenerate quickly. Porang can produce seeds in the first year so that after harvesting, there is an automatic nursery regeneration. When the aren harvest comes, farmers can utilize the fruit following the culture and characteristics of the Andongrejo community.

The value of the fruit will be doubled after being processed into maturity. Assuming 36 trees in the 0.25 ha plot bear fruit and are harvested at one time and one tree has 1 ton of fruit, then there is $36,000 \mathrm{~kg} / \mathrm{plot}$. After processing, the fruit will double in weight and be valued at IDR7,000. So that one plot can produce as many as $72,000 \mathrm{kgs} / \mathrm{plot}$, with a profit of IDR504,000,000. The Java chili in the plot amounted to 242 plants, the harvest is obtained three months before three years of planting. In one harvest, the yield can reach $2.5 \mathrm{~kg} /$ tree. Wet Javanese chili is valued at IDR12,500/kg from one tree and dry Javanese chili is valued at IDR25,000/kg. Therefore, assuming farmers have processed dry Java chili, the profit gained is IDR6,050,000 in three months. Porang plants that have lower plant habitus sets porang plants that have one meter high plant habitus to require a tight spacing so that in a 0.25 ha plot, it can be planted by 1282 plants. It takes two years for porang to reach a maximum fruit weight of $5 \mathrm{~kg}$. The value of porang fruit in the market is IDR6,000/kg, so that one tree can produce IDR30,000 in one harvest, thus, in two years, one plot can generate a selling profit of IDR38,460,000,-.

\section{Selection of Companion Type}

Aren or sugar palm has been cultivated by the people of Indonesia for a long time with the use of its main products are sap or nira obtained from male palm flowers tapping and sugar palm fruit or kolang kaling obtained from female palm flowers. Aren is a versatile palm used for industry and this plant can produce fruit, sap, and starch, and the utilization of these products can be used as a source of income for the community (Lempang M and Mangopang AD 2012 and Makassar Forestry Research Institute 2012). Aren is an annual plant, large, solitary with a height of up to $12 \mathrm{~m}$ (Ramadani et al. 2008). The second derivative products of this plant flower are to make palm sugar, soft drinks, vinegar, alcohol, and fresheners (Planting Authorities 2010), starch flour, well water filters, and palm brooms. For the case in the Meru Betiri National Park, the community use aren to produce a 'Kolang Kaling', the name in Indonesian, one of the ingredients for making fruit ice. Therefore, the people occasionally search for aren in the Zona Rimba (jungle zone) of the Meru Betiri National Park.

Java chili (cabai jawa) is one of the medicinal plant widely used in Indonesia. Java chili usually lives by climbing and wrapped around a climbing pole with stem $\pm 5-7 \mathrm{~cm}$ in diameter, length of stem segments of 2.93$9.82 \mathrm{~cm}$, and the stem coloured from black to blackish brown. The number of leaves of Java chili plants is between 3.95-14.46 leaves per branch. The first harvest of Java chili is usually conducted 3 years after planting when using climbing tendrils, whereas if using worm tendrils, optimal harvesting is carried out 5 years after planting, with 3-5 stages of picking in one season (Arifiyanti et al. 2009). Some Java chili fruits were selected for different production centers based on the area of origin of planting. Java chili has a weight of wet fruit between 82.22-170.35 grams and the weight of dried fruit is between 23.75-51 grams (Arifiyanti et al. 2009).

Porang is one of the tubers that is native to the TNMB area. Plants in the Araceae family have shrub habitus (Herba) and can be found in tropical and subtropical regions (Sumarwoto 2005). Porang has different local names in each region, such as in Andongrejo Village, Andongrejo Resort Ambulu people call it Lorkoh/Lorkong. Porang tubers contain carbohydrate-shaped polysaccharides, and this 
carbohydrate derivative is called glucomannan which has water-soluble properties and can be fermented (Sari and Suhartati 2009). Glucomannan has industrial benefits which can be used as paper adhesives and fillers for the manufacture of tablets (drugs) (Sari and Suhartati 2009). The chemical structure of glucomannan is similar to cellulose so it can be used in making celluloid, explosives, electrical insulation, negative film material, toilet materials, cosmetics, and compacting agents in tissue culture media (Pradipta and Mawarani 2012). Porang tubers containing $\pm 55 \%$ glucomannan can be used for making biodegradable plastics. The details about plants using in the agroforesty wins model can be seen in Figure 2 and Figure 3 below.

\section{Strategy Analysis}

The results of this agroforestry strategy analysis are used to determine the appropriateness of the system to be applied to the national park rehabilitation zone. This alternative strategy is in the form of an effort through an internal-external matrix to know the business position

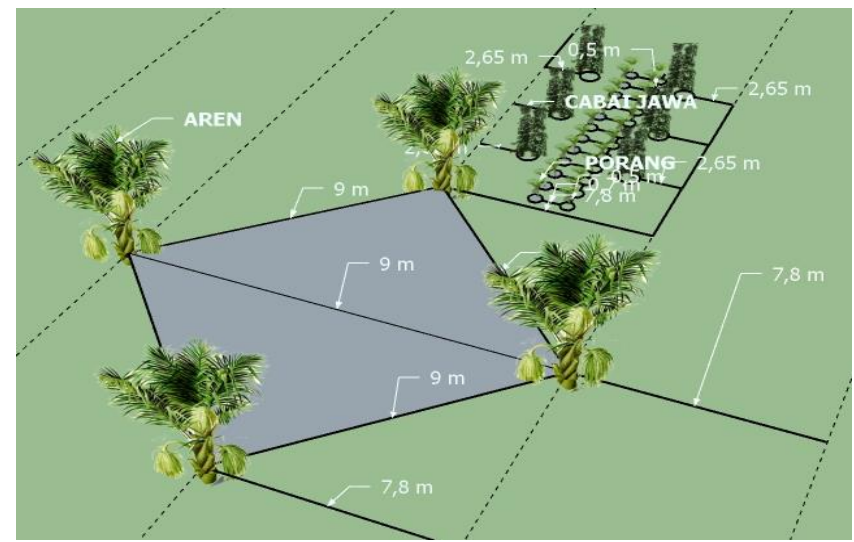

Source: Aren: http://bibdigital.rjb.csic.es/; Java Chili: suksescabejamu; Porang: tanipedia.co.id

Figure 2 Overall agroforestry model.

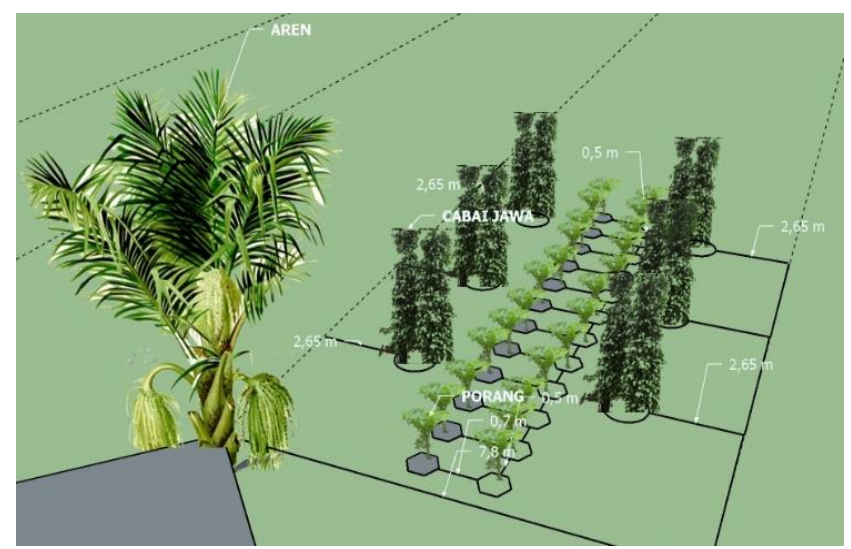

Source: Aren: http://bibdigital.rjb.csic.es/; Java Chili: suksescabejamu; Porang: https://tanipedia.co.id/

Figure 3 Agroforestry constituent plants (Arenga pinnata, Piper retrofractum, Amorphophallus muelleri). that must be carried out, so that in the future it will become a "Win-win Solution" for related parties.

\section{The Strategies for Aren-Agroforestry Management and Development}

Internal factors. Based on the results of field observations and interviews that have occurred and formed the involvement of the relationship between the communities around the forest, namely the buffer villages, one of them Andongrejo village with the Meru Betiri National Park. The involvement of the community around the forest will lead to several internal variables of a degree of importance to each other. The results of the internal weighting and factor rating are shown in Table 1.

External Factors. Based on the results of field observations and interviews that have occurred and formed the involvement of the relationship between the implementer of the conservation area policy, namely the national park and the community with stakeholders who influence the course of national park regulation. This involvement of the community with stakeholder will lead to several external variables having different degrees of importance to each other. The results of the external weighting and factor rating are shown in Table 2.

Based on the results of the SWOT analysis in Table 3 , agroforestry efforts in the rehabilitation zone can be positioned in quadrant III (Figure 4). The appropriate strategy in this position is to support a turn-around strategy, in addition to the need for efforts to minimize internal problems to take advantage of opportunities. The strategy used is WO (Weakness-Opportunity). Some alternative strategies can be developed based on variables.

Strategy I. Increasing public awareness of the urgency of the preservation of national park areas to build economic, ecological, and social awareness (W2, W5, W6, O2, O5, O6). Efforts to develop community intelligence by mobilizing all fields of forestry science are done so that motor skills and knowledge work together in the form of real work to build a better economy. These skills and knowledge can take the form of activating small community business partners and making the community's institution functions effectively.

Strategy II. Formulating policies to support agroforestry as a strategic management effort (W1, W2, W3, W4, O1, O2, O6). The role of government is very important here because the highest legal entity is can move the masses massively through strict and clear regulations. Formulating policies through a policy instrument must look at its objectives, there are policies intended at the farm level (Usaha Tani); at the level of prices, institutions, or technology; at the trade level (quota, export tax); or in macroeconomics (Djogo et al. 2003). Policy formulation is certainly based on internal and external factors in Jember and Banyuwangi as a whole, so that the policies made can be measured and tested. 
Table 1 Internal factor matrices

\begin{tabular}{|c|c|c|c|}
\hline Internal factor & Quality & Rating & Score \\
\hline \multicolumn{4}{|l|}{ Strengths } \\
\hline The existence of agroforestry development community groups. & 0.20 & 2 & 0.40 \\
\hline Availability of land resources. & 0.18 & 4 & 0.72 \\
\hline Availability of labour & 0.17 & 3 & 0.51 \\
\hline Local wisdom that is still maintained. & 0.15 & 3 & 0.45 \\
\hline The availability of a subscription market. & 0.14 & 3 & 0.42 \\
\hline \multirow[t]{2}{*}{ Additional sources of opinion. } & 0.16 & 4 & 0.64 \\
\hline & & Total & 3.14 \\
\hline \multicolumn{4}{|l|}{ Weaknesses } \\
\hline The lack of government support. & 0.18 & 3 & 0.54 \\
\hline Lack of knowledge about the rehabilitation community & 0.18 & 3 & 0.54 \\
\hline $\begin{array}{l}\text { Agroforestry system of planting rehabilitation zone with plants } \\
\text { agriculture. }\end{array}$ & 0.17 & 4 & 0.68 \\
\hline $\begin{array}{l}\text { There is no agroforestry management and planting model yet } \\
\text { strategically. }\end{array}$ & 0.14 & 3 & 0.42 \\
\hline Limited information and access. & 0.16 & 3 & 0.32 \\
\hline \multirow[t]{2}{*}{$\begin{array}{l}\text { Lack of good relations between the community, agencies and } \\
\text { related institutions. }\end{array}$} & 0.21 & 4 & 0.81 \\
\hline & & Total & 3.31 \\
\hline
\end{tabular}

Table 2 External factor matrices

\begin{tabular}{|c|c|c|c|}
\hline External factor & Quality & Rating & Score \\
\hline \multicolumn{4}{|l|}{ Opportunities } \\
\hline Availability of aren, cabai jamu, and porang seeds & 0.18 & 4 & 0.72 \\
\hline Overcoming the problem of regional policy enforcement & 0.19 & 3 & 0.57 \\
\hline The emergence of village business development & 0.15 & 2 & 0.30 \\
\hline The ability to trigger the development of other sectors & 0.13 & 3 & 0.39 \\
\hline Opened the city market between islands & 0.18 & 2 & 0.36 \\
\hline \multirow[t]{2}{*}{ Collaboration with stakeholders such as college institutions and NGOs } & 0.17 & 2 & 0.34 \\
\hline & & Total & 2.68 \\
\hline \multicolumn{4}{|l|}{ Threats } \\
\hline $\begin{array}{l}\text { Lack of community awareness of land use rehabilitation } \\
\text { Farmer management attention is greater towards }\end{array}$ & 0.18 & 4 & 0.72 \\
\hline crops & 0.19 & 4 & 0.76 \\
\hline \multicolumn{4}{|l|}{ The distance between planting aren and intercropping plants is too } \\
\hline \multicolumn{3}{|l|}{ Lack of intensive maintenance of plants } & 0.54 \\
\hline Pests and plant diseases & 0.13 & 1 & 0.13 \\
\hline & & Total & 2.45 \\
\hline
\end{tabular}

Strategy III. Education and counseling, as a strengthening of the role of extension workers, so those good relations are established between communities, researchers, NGOs, and related agencies. (W1, W2, W4, W5, W6, O3, O6). The form of success of a program is related to the quality of cooperation between the parties concerned, such as counseling from the initiator of the facilitator or assistant who has the ability and knowledge related to technical, financial, and marketing to farmers to better know, be willing, and able to support forestry development. The socialization carried out by MBNP in Ecosystem Restoration in 2017-2018 and $2018-2019$ is quite able to move the community to participate in implementing this program. Numerically, the percentage of plant life in Andongrejo Village in $2017-2018$ ranged from 10\% - 43\% and in 2018-2019 it was around $2.67 \%$. This decrease was caused by several aspects, mainly after assistance planting that still needs to be improved.

Strategy IV. Facilitating access to relevant data across all participating institutions and is supported in a multidisciplinary manner, in the form of research activities that produce an appropriate agroforestry design on rehabilitation zone. (W2, W3, W4, W5, W6, 01, 03, 04, 05, 06). Also, to gain support from the government, real efforts can be made and the potential for success of a program is in the form of studies that produce a system pattern or design of agroforestry management that is suitable on rehabilitation zone. The development of an aren-based agroforestry system is used as a solution in finding the midpoint of a problem between policy enforcement and meeting the economic welfare of the community. The results of this research can later become a data access facility that is relevant and logical in all relevant and supportive institutions. 
Table 3 SWOT analysis matrices

\begin{tabular}{|c|c|c|}
\hline EFAS & $\begin{array}{l}\text { Strengths (S) } \\
\text { 1. The existence of agroforestry } \\
\text { development community groups. } \\
\text { 2. Availability of land resources. } \\
\text { 3. Availability of labour } \\
\text { 4. Local wisdom that is still } \\
\text { maintained. } \\
\text { 5. The availability of a subscription } \\
\text { market. } \\
\text { 6. Additional sources of opinion. }\end{array}$ & $\begin{array}{l}\text { Weaknesses }(\mathrm{W}) \\
\text { 1. The lack of government support. } \\
\text { 2. Lack of knowledge about the } \\
\text { rehabilitation community } \\
\text { 3. Agroforestry system of planting } \\
\text { rehabilitation zone with plants } \\
\text { agriculture. } \\
\text { 4. There is no agroforestry management } \\
\text { and planting model yet strategically. } \\
\text { 5. Limited information and access. } \\
\text { 6. Lack of good relations between the } \\
\text { community, agencies and related } \\
\text { institutions. }\end{array}$ \\
\hline $\begin{array}{l}\text { Opportunities } \\
\text { 1. Availability of aren, cabai } \\
\text { jamu, and porang seeds } \\
\text { 2. Overcoming the problem of } \\
\text { regional policy } \\
\text { enforcement conservation } \\
\text { 3. The emergence of village } \\
\text { business development } \\
\text { 4. The ability to trigger the } \\
\text { development of other } \\
\text { sectors } \\
\text { 5. Opened the city market } \\
\text { between islands } \\
\text { 6. Collaboration an with } \\
\text { stakeholders such as } \\
\text { college institutions and } \\
\text { NGOs a }\end{array}$ & $\begin{array}{l}\text { Strategi SO } \\
\text { Developing a planting model / } \\
\text { pattern agroforestry for the } \\
\text { community to restore the function } \\
\text { of the rehabilitation zone } \\
\text { ecosystem (S1, S2, S3, O1, O2) } \\
\text { Developing a partnership pattern } \\
\text { with related and interested parties } \\
\text { to improve the economic welfare of } \\
\text { the village. (S1, S3, S4, S5, S6, } \\
\text { O3, O4, O5, O6) networking of } \\
\text { Increase for community } \\
\text { cooperation and involvement of all } \\
\text { stakeholders for } \\
\text { empowerment (S1, S3, S4, O3, } \\
\text { O4, O6) the results of } \\
\text { Optimizing the } \\
\text { intercropping integration (S1, S2, } \\
\text { O1, O3) }\end{array}$ & $\begin{array}{l}\text { Strategi WO } \\
\text { - Increase public awareness of the } \\
\text { importance of preserving the national } \\
\text { park area to build economic, ecological } \\
\text { and social awareness. (W2, W5, W6, } \\
\text { O2, O5, O6) } \\
\text { - Formulating policies to support } \\
\text { agroforestry as a strategic management } \\
\text { effort (W1, W2, W3, W4, O1, O2, O6) } \\
\text { - Education and counseling, to } \\
\text { strengthen the role of extension } \\
\text { workers, so that good relations are } \\
\text { established between the community, } \\
\text { researchers, NGOs and related } \\
\text { agencies. (W1, W2, W4, W5, W6, O3, } \\
\text { O6) } \\
\text { Facilitating access to relevant data } \\
\text { between participating institutions and } \\
\text { supported in a multidisciplinary manner } \\
\text { in the form of research activities that } \\
\text { produce appropriate agroforestry } \\
\text { designs on the rehabilitated zone. (W2, } \\
\text { W3, W4, W5, W6, O1, O3, O4, O5, O6) }\end{array}$ \\
\hline $\begin{array}{l}\text { Threats } \\
\text { 1. Lack of community } \\
\text { awareness of land use } \\
\text { rehabilitation } \\
\text { 2. Farmer management } \\
\text { attention is greater towards } \\
\text { crops } \\
\text { 3. The distance between } \\
\text { planting aren and } \\
\text { intercropping plants is too } \\
\text { narrow } \\
\text { 4. Lack of intensive } \\
\text { maintenance of aren plants } \\
\text { and intercrops } \\
\text { 5. Pests and plant diseases }\end{array}$ & 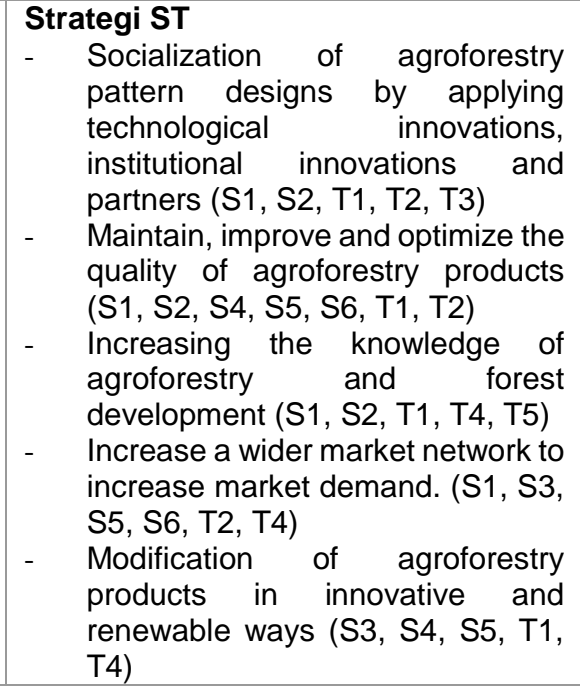 & $\begin{array}{l}\text { Strategi WT } \\
\text { - Management collaboration to program } \\
\text { evaluation to determine the best } \\
\text { strategy accuracy (W1, W4, W6, T1, } \\
\text { T4) } \\
\text { Make the examples of agroforestry } \\
\text { system implementation models and } \\
\text { carry out regular monitoring to } \\
\text { measure the success rate (W3, W4, } \\
\text { T3, T4, T5) on } \\
\text { The involvement of the government, } \\
\text { stakeholders and communities in } \\
\text { implementing agroforestry and } \\
\text { rehabilitation programs (W1, W5, W6, } \\
\text { T1, T2) }\end{array}$ \\
\hline
\end{tabular}

\section{CONCLUSION}

Utilization of aren by the community in Meru Betiri National Park in the form of aren fruit which is processed into kolang-kaling is obtained from the jungle zone. This utilization of aren by the community is not following the Meru Betiri National Park policy, however another use that is still permitted is the agroforestry system in the rehabilitation zone. This research related to the agroforestry system utilizing three native plants of MBNP, e.g., aren, java chili, and porang.

The study shows that the concept of agroforestry "wins" -win-win strategy-based aren, provide ecological benefits to the management of Meru Betiri National Park, while for the people get prosperity from the exploitation of sugar palm, java chili, and porang in the 


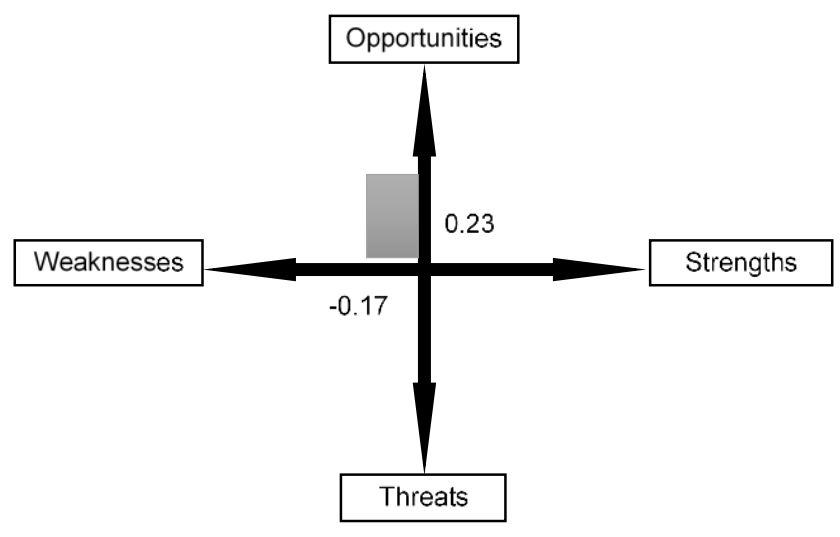

Figure 4 SWOT analysis diagram.

rehabilitation zone land. This model can be used as a reference for conservation areas, especially the Meru Betiri National Park is carrying out agroforestry systems based on a SWOT analysis. The analysis obtained 4 strategies, namely: strategy I, increasing public awareness of the urgency of the preservation of national park areas; strategy II, formulating policies to support agroforestry as a strategic management effort; strategy III, education and counseling, as a strengthening of the role of extension workers; strategy IV, facilitating access to relevant data across all participating institutions and is supported in a multidisciplinary manner.

\section{REFERENCES}

[KLHK RI] Ministry of Forestry and Environment of the Republic of Indonesia. 2015. Minister of Environment and Forestry Regulation RI No. P.76/Menlhk-Setjen/2015 about the criteria for managing zones of national parks and management blocks of nature reserves, wildlife reserves, forest park botanical garden and nature tourism parks. Jakarta (ID): Ministry of Forestry and Environment of the Republic of Indonesia

Arifiyanti IN. 2009. Studi pertumbuhan cabe jawa panjat (Piper retrofractum Vahl.) di pembibitan dari tiga sentra produksi. [Skripsi]. Bogor (ID): Institut Pertanian Bogor.

Bhagwat SA, Willis KJ, Birks HJB, and Whittaker RJ. 2008. Agroforestry: a refuge for tropical biodiversity?. Trends in Ecology and Evolution. 23(5):261-267. https://doi.org/10.1016/j.tree. 2008.01.005

Djogo T, Sirait MT, Suharjito D. 2003. Kelembagaan dan Kebijakan dalam Pengembangan Agroforestri. ICRAF: Bogor (ID).

Lempang M, Mangopang AD. 2012. Efektivitas nira aren sebagai bahan pengembang adonan roti. Jurnal Penelitian Kehutanan Wallacea. 1(1): 26. https://doi.org/10.18330/jwallacea.2012.vol1iss1 pp26-35

Makassar Forestry Research Institute. 2012. Pohon Aren dan Manfaat Produksinya. Lempang(ID): Mody.

Plantation Authorities. 2010. Prospek pengembangan tanaman aren ( Arenga pinnata merr) mendukung kebutuhan bioetanol di Indonesia. Jurnal Perkebunan. 9(1): 36-46.

Pradipta IMD, Mawarani LJ. 2012. Pembuatan dan karakterisasi polimer ramah porang. Prosiding Pertemuan Ilmiah Ilmu Pengetahuan dan Teknologi Bahan 2012; 2012 Oct 03; Serpong, Indonesia. Serpong: hlm 83-89; [internet] [diakses $2021 \mathrm{Apr}$ 13]. http://digilib.batan.go.id/ppin/katalog/file/14112213-2012-1-083.pdf

Ramadani P, Khaeruddinl, Tjoa A and Burhanuddin IF. 2008. Pengenalan Jenis-jenis Pohon yang Umum di Sulawesi. Palu(ID): UNTAD Press.

Sari R and Suhartati. 2009. Tumbuhan Porang: Prospek budidaya sebagai salah satu sistem agroforestry. Info Teknis EBONI. 12(2): 97-110.

Sumarwoto. 2005.lles-iles (Amorphophallus muelleri Blume): deskripsi dan sifat-sifat lainnya. Biodiversitas. 6(3): 185-190. 